\title{
Recontextualising Genre-Based Pedagogy in Indonesian Context: A Case of Preservice Teachers
}

\author{
Iyen Nurlaelawati, Nenden Sri Lengkanawati, Wawan Gunawan
}

Universitas Pendidikan Indonesia, Bandung, Indonesia, iyenn@upi.edu,nendensl@upi.edu, wagoen@upi.edu

First draft received: 20 Jul 2019 Date Accepted: 23 Dec 2019 Final proof received: 10 Jan 2020

\begin{tabular}{|c|}
\hline Abstract \\
\hline $\begin{array}{l}\text { This study focused on how two preservice teachers applied genre-based pedagogy in their teaching } \\
\text { practices during teaching practicum in order to help their students produce descriptive report texts. Using a } \\
\text { case study design, the data were collected mainly from classroom observation and students' texts. The } \\
\text { findings showed that the preservice teachers had considerably good knowledge of genre-based pedagogy } \\
\text { and of its application of the first two stages of the pedagogy. In the last two stages, they needed more } \\
\text { attention to provide opportunities for the students to practice producing the focus text. In terms of the results } \\
\text { of students' learning, the preservice teachers needed improvement to support and observe the students' } \\
\text { development more closely in writing. This study suggests some evaluative results of how teaching practicum } \\
\text { should support and help preservice teachers develop their professionalism in the field of EFL teaching. } \\
\text { Keywords: genre-based pedagogy; preservice teachers; recontextualisation }\end{array}$ \\
\hline $\begin{array}{l}\text { To cite this paper (in APA style): } \\
\text { Nurlaelawati, I., Lengkanawati, N. S., \& Gunawan, W. (2020). Recontextualising genre-based pedagogy in } \\
\text { Indonesian context: A case of preservice teachers. International Journal of Education, 12(2), 80-91. doi: } \\
10.17509 \text { /ije.v12i2.23394. }\end{array}$ \\
\hline
\end{tabular}

\section{INTRODUCTION}

Genre-based pedagogy has given influence in writing instruction for more than two decades (Hyland, 2007). Originally developed in Australia to teach writing in L1 context, it has been adapted in various teaching contexts including ESL/EFL contexts (Cahyono, 2017; Emilia \& Hamied, 2015; Worden, 2018), CLIL contexts (Lo \& Jeong, 2018), and in the teaching of other subjects such as social studies (de Oliveira \& Lan, 2014). This pedagogy has also supported both preservive and inservice teachers to assist their students to produce effective and relevant texts (Hyland, 2007).

Genre-based pedagogy focuses on how to teach a language to learners so that they can use language patterns to produce purposeful pieces of writing (Hyland, 2003). It aims to teach learners how to use language patterns to produce coherent, purposeful piece of writing (Christie \& Derewianka, 2008). It elaborates the functions of language as a system of choices to communicate certain functions; that is a system in which people can express their experiences of the world, interact with others and create coherent messages (Hyland, 2003), because the approach sees writing as a social and cultural practices (Hasan \& Akhand, 2010). In this pedagogy learners are supported to develop their literacy outcomes (Knapp \& Watkins, 2005). The success of the implementation of genre-based pedagogy, especially in EFL classes has been reported around the world such as in Chile (Burgos, 2016) Norway (Horverak, 2016), China (Min, 2014), and Colombia (Noreiga, 2016).

The teaching and learning cycle of genre-based pedagogy developed by Rothery (1994) shows the stages of deconstruction (preparation and modelling), joint construction and independent construction. The first stage of learning provides learners to experience and explore the cultural and situational aspects of the social context of the focus text. The activities in this early stage are made to familiarize learners with the topic of the genre, and the vocabulary and grammar in the genre (Derewianka, 2003). The activities include introduction and reading. Learners are then introduced to the model texts that belong to the focus genre in modelling stage. In this stage learners are made aware of the structure and linguistic features of the model texts. They also learn the grammar in the context of the text (e.g. the present tense, personal pronouns, etc.) (Hyland, 2003). In joint construction stage learners as a class or in small groups, guided by teachers, construct a text of the focus genre using the knowledge of the topic built in the first and second stages (Derewianka, 2003). When they are ready, they can write their own texts independently and 
individually through drafting, revising, and editing the texts (Gebhard \& Harman, 2011).

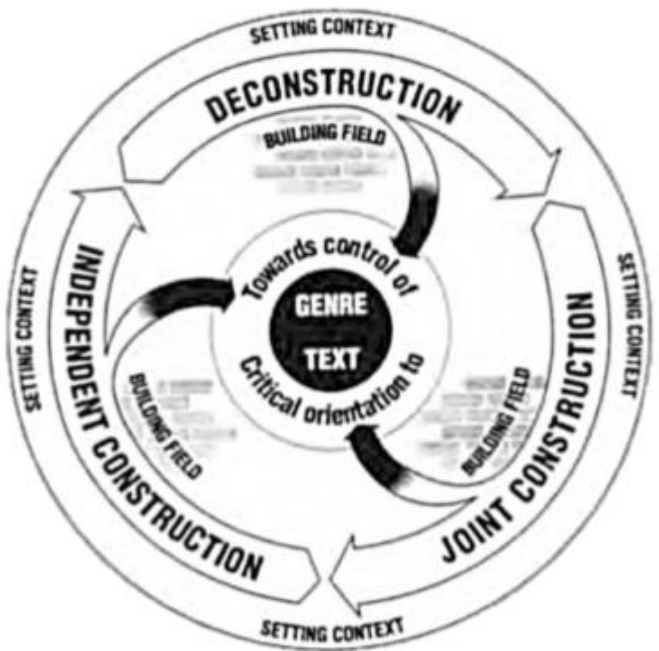

Figure 1 Teaching/Learning Cycle (Rothery, 1994)

Most of the studies that applied genre-based pedagogy were conducted by experienced teachers in the context of teacher education so that it can be assumed that the teachers were knowledgeable about teaching and had good experience in managing the class in order to provide appropriate lessons for their students. Rodriguez and McKay (2010) define experienced teachers based on their years of teaching and their ability to manage their classes effectively. Little studies reported EFL teaching and learning using genre-based pedagogy in the classroom by preservice teachers, particularly those who are pursuing their teaching certificate. Thus, this study attempts to explore the practice of genre-based pedagogy in EFL classrooms in a lower secondary school in West Java Province, Indonesia. Specifically, it seeks the answer to how EFL preservice teachers helped the students to write descriptive texts within the framework of genre-based pedagogy. This study is significant to do because it informs the practice of genre-based pedagogy by preservice teachers in Indonesia, and it will also contributes to the aspects of genre-based pedagogy that helps Indonesian students to write better texts.

\section{GENRE-BASED PEDAGOGY IN INDONESIA}

Genre-based pedagogy, or as it is known in Indonesia, genre-based approach, has been incorporated into the Indonesian English language curriculum for more than a decade. Introduced for the first time in the 2004 Curriculum (Emilia, E., 2011a), it remains salient in the latest curriculum, called the 2013 Curriculum (Kemdikbud, 2013). The purpose of the approach in the curriculum is to enable students in lower and upper secondary school to develop their English integrated language skills by ways of engaging with different types of texts such as descriptive, narrative, recount, procedure, factual report, and analytical exposition texts. The change from the previous curriculum to the 2004 Curriculum was considered a significant paradigm shift. In the previous curriculum (before the 2004 Curriculum) the teaching of English language was viewed as structural, teaching vocabulary and grammar in isolation. Since the application of the 2004 Curriculum, the teaching of English has emphasized the four language skills and the importance of students learning language in the context of whole texts and meaningful activity. This is relevant to the claim of genre-based approach theories that context is an important aspect of learning a language (Feez, 2002).

Despite the inclusion of genre-based pedagogy in the national curriculum for teaching English in lower and upper secondary school, most studies related to the implementation of genre-based pedagogy were reported to be conducted in tertiary level of education (Aunurrahman, Hamied \& Emilia, 2017; Emilia \& Fuad, 2015; Hariyanto, 2001). Very limited, if not any, studies have been conducted in secondary school, such as Pujianto, Emilia and Ihrom (2014) and Kartika-Ningsih and Gunawan (2019). Pujianto et al. (2014) reported that the implementation of genre-based pedagogy would help students write a text, e.g. report text, in conditions that the students received rich exposures and individual guidance (especially in the stages of modelling, joint construction and independent construction.

Findings reported by Kartika-Ningsih and Gunawan (2019) are interesting in which the article identified the recontextualisation of the model of genre-based pedagogy. English teachers in Indonesia recontextualised the model due to the influences of other teaching approaches that they learned prior to the pedagogy. This Indonesian model is similar in cycle but with teacher-considered important focus of activities. The activities in each stage are believed to support students to master the focus genre. For example, stage of building knowledge of field is intended to familiarize students with the focus genre through activities such as reading, listening, and speaking variety of texts, in order to be able to identify new words or phrases and the grammar used in the texts. In modelling stage, the activities are mostly teacher-oriented in which teachers explain the structure and language features of text, and students' complete exercises. The students' understanding of the focus text is exercised in joint construction stage in three alternative ways: no joint construction, writing a new text by teacher and students together, or writing a new text by students working in groups. In the independent construction, students write a new text individually and independently. They are provided time to draft, consult, and edit their text. 


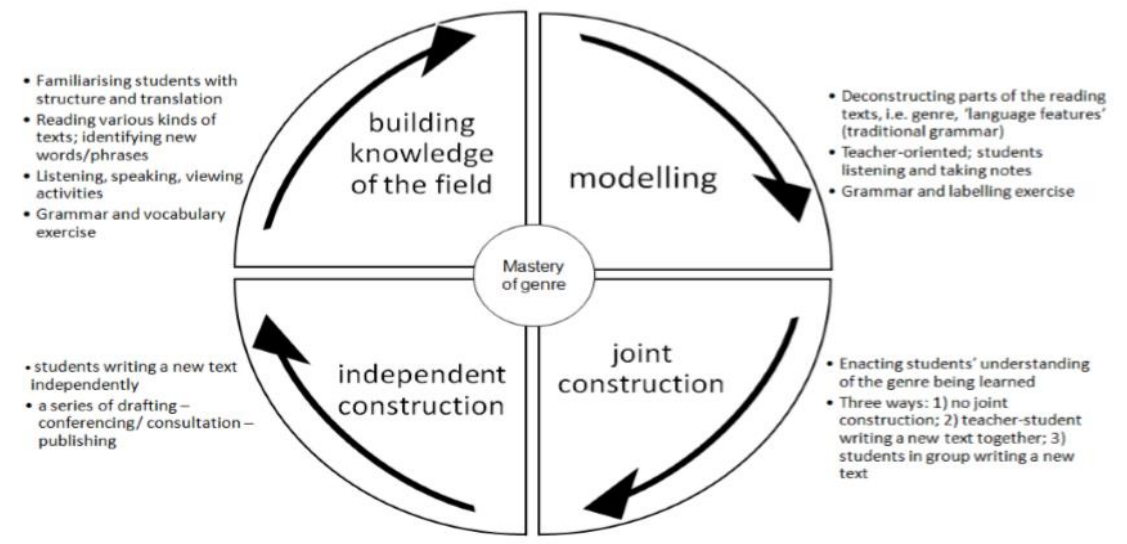

Figure 2 A model of teaching/learning cycle in the Indonesian GBA (Kartika-Ningsih \& Gunawan, 2019)

\section{PRESERVICE TEACHERS IN TEACHING PRACTICUM AND GENRE-BASED PEDAGOGY}

Many purposes are identified when student teachers are having school-based teaching practicum. Teaching practicum is purposed to enhance the value of learning experience that integrates work and education (Gardner \& Bartkus, 2014). It provides professional training to preservice teachers that is related to fieldwork and allows them to gain extensive real-world experience in the classrooms (Simons et al, 2012; Tuli \& File, 2009, Ragawanti, 2014). Teaching practicum helps student teachers to develop professionally and to shape their beliefs and thinking about teaching (Mtika, 2011). This practice also allows student teachers to experience and experiment their knowledge and skills in the real world of teaching and learning (Kennedy, 1996, in Goh \& Matthews, 2011). In developmental sense, student teachers can continue to develop, adapt, and explore teaching as a career long process through teaching practicum (Gebhard, 2009).

Genre-based pedagogy is a realization from Halliday's theory of language for language teaching and learning. It overviews language learning in two pivotal dimensions, text and context. Text is a meaningful passage of language that hangs together to serve some special purpose, and context refers to environment that surrounds the text (Christie, 2004). They are interrelated in ways that "texts are always produced in a context" (Knapp \& Watkins, 2005) because people produce texts for specific purposes in a particular social environment. The pedagogy, thus, demonstrates how language works for different purposes in the contexts it is used. To see the connection of text and context, teachers need a tool called register that can show the social cultural setting where the speaker is doing his activity and the language that is a part of that activity. The tool provides the opportunity for teachers to identify the elements of language use in context, and to mediate their explanations of language to their students to help them understand how to use the language. The register includes the field (what is happening in the activity), the tenor (who is participating in the activity), and the mode (the role of language is playing in the activity) (Eggins, 1994).

EFL teacher education program has a significant role to support preservice teachers to understand the principles and implementation of genre-based pedagogy to language teaching that include inseparable knowledge about language and knowledge about teaching. In the implementation of genre-based pedagogy, a teachinglearning cycle is developed to help teachers support students in learning to write in the school texts.

Several studies in teacher education found that genre-based pedagogy is not always practiced as recommended. Adaptation towards the stages and the activities within the stages are found across different level of education. Yasuda (2011) argues that modification of genre-based instruction can create an important pedagogical link between socially situated writing performance and choices of language use. An example of adapted genre-based pedagogy is from de Oliveira and Avalos' study (2018) who identified a social-studies teacher, who was engaged in a Master's degree of education, modified the stages of genre-based pedagogy in their study in the USA. The purpose of the lesson was to teach students how to write introductory paragraphs for an essay assignment in a 9th grade history classroom. The teacher designed and implemented the stages of building the field, assessing understanding and prewriting, and deconstructionan and co-construction. The result showed that the students were so engaged with the writing assignment. In addition, particularly in coconstruction stage, the students experienced how to write an introduction, reviewed important information of the source text, and were more confident about their writing. More important result of genre-based pedagogy application to the students was the students were confident to continue writing.

Correa and Echeverri (2017) explored a study involving EFL preservice teachers in Academic writing course using genre-based pedagogy, specifically teaching to write information report. The modification of the activities within the approach can be seen from the first two stages, preparation and modelling stages. In the 
preparation stage the activities included the teachers' presentation, analysis of information report and group reading of sample texts. In the modelling section the lesson included activities "to get the preservice teachers understand how context, purpose, and audience influenced and were influenced by language features of texts". Meanwhile, the joint construction and independent construction stages were conducted as through modelling skimming and scanning information, constructing a concept map, building an outline, drafting, proofreading and editing. In the end the preservice teachers constructed their own texts.

The instructions of learning about genre-pedagogy in teacher education is suggested to be comprehensive in ways that preservice teachers are exposed to the trainings of writing and systemic functional grammar and its pedagogy. Yayli (2011) argues that in order to understand how language is taught functionally, preservice teachers should experience the instruction using genre-based pedagogy of how texts are constructed. This experience leads to candidate teachers' awareness of genre and its learning. Experiencing genre-based pedagogy and being aware of genre does not suffice in that preservice teachers also need exposures other aspect of language teaching. Language teacher education should provide courses that can explore the theory of functional linguistics that focuses of language learning and the instructions that provides scaffolding for students to learn how language functions based on the purpose and the culture where the language is used are (Gebhard, Chen, Graham, \& Gunawan, 2013). However, when the pedagogy is practiced, modifications and transformation of teaching and learning should not be avoided when teachers make lists considerations of how to support their students to learn language (Worden, 2019).

\section{THE STUDY}

The context of this study was a teacher certification program for bachelor's degree participants in EFL education. This program was a one-year teacher education program held by the government in cooperation with a state university in West Java, Indonesia, in which the participants would gain a national teaching certificate. The program provided courses related to EFL language teaching and learning and civil country defense. The EFL language teaching and learning related courses covered language skills, EFL teaching and learning, lesson planning, and classroom action research. Genre-based pedagogy was introduced and discussed in the course of EFL teaching and learning along with another teaching method such as scientific approach. Genre-based pedagogy and scientific approach method are two teaching and learning methods highly suggested by the current national curriculum. Teaching practicum was the last course the preservice teachers had to take before they graduated from the program, that lasted for about 3 months in a partner school. English language subject was taught two times a week with each time lasted for 80 minutes.
This study used a case study design, in which it provided a unique example of real people in real situations (Cohen et al, 2007). It attempts to describe how preservice teachers implemented genre-based pedagogy to help their students construct texts during their teaching practicum program. The participants $(n=2)$, Farhan and Gilang (pseudonyms), were selected among 20 preservice teachers in the teacher certification program. Both were male teachers aged 25-27 years old. Their teaching experience before joining the teacher certification progam was 1-3 years. They were selected for their willingness to be observed during the implementation of genre-based pedagogy.

At the time of this study, Farhan and Gilang were teaching a basic competence stipulated in the national curriculum that is to ask and to give information, both oral and in written, related to things around us, including objects, animals, and public buildings (Standard No. 4.4) and to self-introduction (Standard No. 4.2) respectively. They taught the topics to the seven grade EFL classes, consisting of 30-35 students, at a lower secondary school in West Java, Indonesia. The topics are related to descriptive reports. Descriptive report has the structure of a title, general statement to identify the entity and description that describes particular features, characteristics, activities, and behaviors (Derewianka \& Jones, 2016). Farhan focused on teaching descriptive report of public building, particularly describing certain parts of the students' school such as canteen, parking lot, classroom, garden, etc.; and Gilang on describing one self and his/her family. Both allocated four meetings for the topics using genre-based pedagogy. Each meeting for both Farhan and Gilang's classes lasted for 80 minutes.

Prior to joining the teacher certification program, Farhan and Gilang had different start of exposure to genre-based pedagogy. Farhan learned genre-based pedagogy for the first time in one of the courses in his bachelor's degree, while Gilang had heard about the pedagogy but was not really sure what the pedagogy was and how to apply it. In this study they reasoned that they implemented genre-based pedagogy due to their cooperating teacher's recommendation since the school where they were doing their teaching practicum was a model school of genre-based pedagogy. Despite being recommended, both preservice teachers believed that genre-based pedagogy had stages that could help his students to achieve the national standards, especially description of self and description of environment orally and in written.

\section{DATA COLLECTION AND ANALYSIS}

The data of the study were collected through classroom observations and students' texts, Classroom observations were conducted to identify the stages of genre-based pedagogy and to look closely to which activities students were helped to write descriptive texts. The classes were recorded using an audio-visual device to confirm the fieldnote during the observation. The students' texts were also analyzed to see the result of the teaching and learning cycle. The data from the classroom 
observation were transcribed verbatim and analysed based on the activities in each stage of genre-based pedagogy. The analysis emphasised on how the activities, especially the special techniques, clustering technique and watching videos, supported the students to write the assigned texts. Students' texts were analyzed based on register analysis, identifying the structure and the language features. Based on the analysis the data are presented in two descriptions, teaching and learning activities and students' descriptive texts, along with their interpretations.

\section{FINDINGS \\ Preservice Teachers' Actions to Support Students' Learning}

The preservice teachers in this study conducted variety of activities in the order to help their students be able to construct the target texts as mandated in the national basic standard. Both claimed to use genre-based pedagogy in their lesson and their intentions in the lesson were to support the students to construct texts of describing things around us, especially rooms in the school, and self-introduction. The data findings are displayed in the order of the stages of genre-based pedagogy as perceived by the preservice teachers in this study, building knowledge of field, modeling, joint construction, and independent construction.

\section{Building knowledge of field}

To begin the unit, it is important to prepare students to reading and writing through introducing and discussing the topic. This part familiarizes students with the topic, e.g. descriptive report so that they are ready for guided reading and discussion. In Farhan's class, the unit was introduced through watching two videos describing the classrooms in two different countries, one in Africa and the other in Europe. Before watching the videos, Farhan elicited vocabularies especially asking students to mention the objects students could find in the classroom. The vocabularies related to classroom objects were two objects (table and chair) as identified in the excerpts.

\footnotetext{
T: We will describe two different countries. Kalian sudah mengetahui kira-kira kalau di Indonesia, or here in your class, what's the thing that you can see, what the things or objects that you can see, besides me. I am not a thing, I'm a human.

S1: Table

T: Table. Good. What else?

S2: Chair.

T: Chair. Many things, right?

T: Now, sekarang, dengarkan. Bapak bagi jadi enam kelompok ya. First group, second, third, fourth, fifth and sixth. Now, you will see two videos from two different countries and you will identify the objects or the things that belong to the class. Kalian akan menulis, kalian akan menyebutkan tiga object yang ada di kelas tersebut. Excerpt 1 Farhan's Class in Meeting 1
}

Farhan did not discuss the content of the videos after watching the videos, instead he asked the students in the groups to mention several objects they could find in the first and second videos. He also asked the students to put sticky notes on objects in their classroom. The next lessons were on the explanation and exercises of grammar such as plural (these and those) and prepositions. No texts were identified in this stage, only the videos showing two different classroom situations in two different countries without further discussion on them.

In the other class, Gilang provided more varied activities in his class with the support of electronic (videos, audios and slide show) and printed media (a page of a book) in order to give input of introducing oneself and his/her family. He allocated three meetings to discuss each of the subtopics, Meeting 1 exploring how to introduce oneself, Meeting 2 expansion of selfintroduction (hobbies and favorites), and Meeting 3 family members. On Meeting 1 he started the unit by showing a video of someone's introduction and asked his students the topic covered in the video. He expected the students to make prediction of what they were about to learn. The students replied in Indonesian language that they would learn about introduction, and Gilang affirmed in English. Similar to Farhan's class, there was no discussion on the content of the video. Gilang invited the students to play a throwing ball in which they had to introduce themselves once they caught the ball. The activity initiated by Gilang who provided an example of how to do self- introduction. The introduction was relatively short including only the students' name e.g. My name is Gilang.

After playing the game, Gilang moved to showing a text of his introduction displayed on the screen. The text includes greeting, introducing a name, spelling the name, telling an address, and a closing. He, then, pointed some students to tell their addresses by asking Where are you from? and Where do you live?. The students could respond to the questions without problem, including when they introduced their names in English. They seemed to have been familiar with the questions, in regards with their beginning level of learning English. Another video was displayed to the students showing a short conversation of asking name and name spelling. This video was used to identify the expressions used by the speakers when saying their names, asking someone's name and spelling names. 


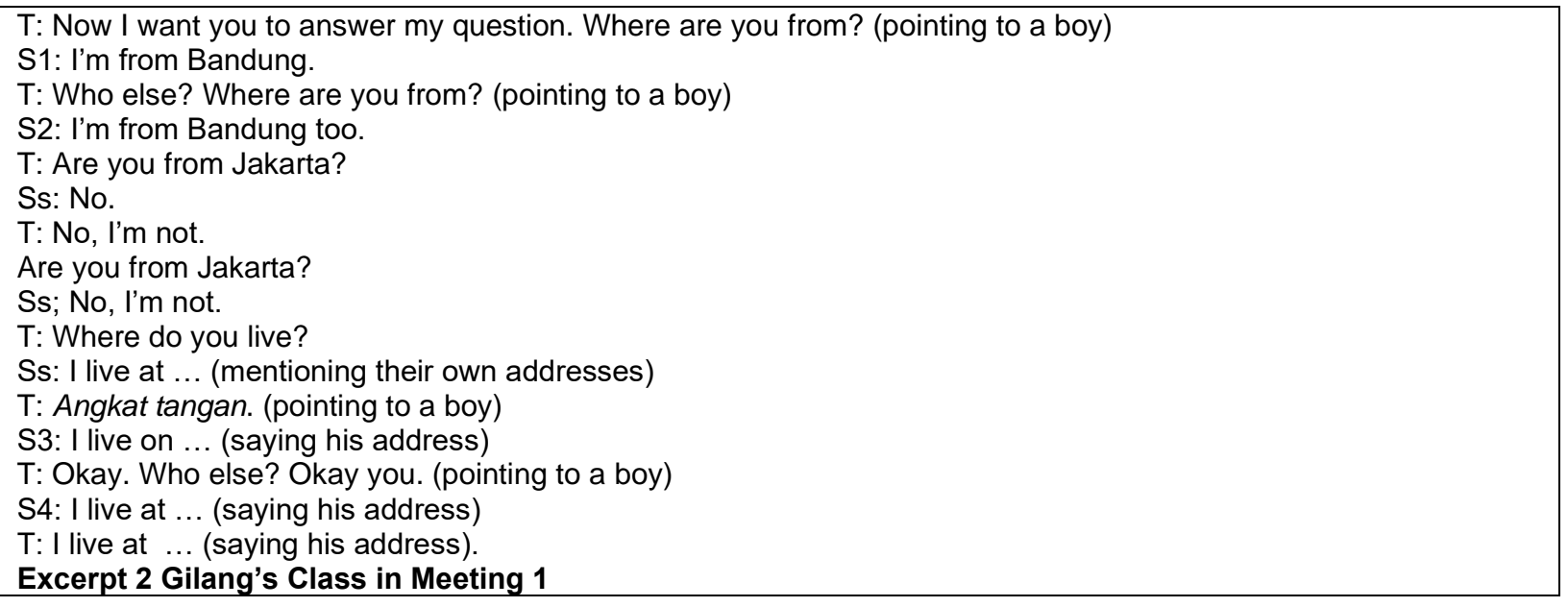

In Meeting 2 and Meeting 3, Gilang exposed vocabularies of someone's identity and interests, and someone's family members through audios. The discussion on someone's identity was expanded in Meeting 2 by adding more information about hobbies and favorites (color, food, and drink). While, in Meeting 3 the discussion was of an Indonesian celebrity's family and doing questions and answers related to the students' family members. The students listened to the audio for several times, he asked some questions orally related to the audio such as the name of the speaker and the family members the speaker had. The students were also asked about their family members such as the number of brothers or sisters, the numbers of their family members, and the names of their fathers and mothers. As in Meeting 1, the students seemed to have no difficulties in responding the teacher's questions, when asked individually or as a class.

\section{Modelling}

The next stage of genre-based pedagogy is modelling where students are exposed to a model of the text expected to be written by the students. The activities in this stage includes unpacking the context and language of the text such as the purpose and the structure of the text, and the linguistic features used in the text. In his class, in order to enable his students to describe parts of their school, Farhan showed a video of a person describing a building in the United States of America. While watching the video, the students were expected to write what the person described on their note books. There was no written guidance or worksheet in this activity and no particular discussion on the video that the students watched. This watching activity lead the students to work in groups of two or three to go to certain rooms in the school, for example library, school clinic, games hall, parking lot, art room, canteen, etc. Each group headed to one particular room and identified the objects in that room and returned to the classroom afterwards.

Several strategies were used by Farhan in order for his students to be able to describe the rooms in the school. He gave the students an exercise of singular and plural form of objects. In the last meeting a sample text was also presented right before the students worked in groups to construct their description (discussed in independent construction). The sample text showed how a text of describing a house was written. Some phrases were highlighted especially when showing singular and plural objects and prepositions. Farhan emphasized the highlighted phrases for the students to pay attention.

T: Ini ada contoh kalimat pada text descriptif. This is the example of descriptive text. Ini adalah contoh yang harus kalian perhatikan. Yang Bapak garis bawahi ini yang wajib ada di text kalian. For example, waktu itu kita pernah belajar tentang preposition. I live in a small house. Atau, My bedroom is in the left side of the living room. Or, there is a night table next to the bed. Yang lain preposisi gunakan juga. Another example, menunjukkan jumlah $\underline{\text { It }}$ has five rooms. Ada lima ruangan. Kalau kalian menemukan jumlahnya banyak, sebutkan ada berapa jumlahnya dengan menggunakan kalimat seperti ini. Contoh lainnya adalah penggunaan kata a, a living room, penggunaan kata/-s/ five rooms. Itu harus ada. Ini contoh. Jadi tidak ada There is a book, There are five chairs. Tidak ada seperti itu ya. Buat kalimat seperti ini.

Excerpt 3 Farhan's Class Meeting 4

Other strategies are by reminding the students about prepositions through distribution of a piece of paper containing list of prepositions with images so that the students were expected to understand how to select appropriate prepositions in their texts. He also expected the students to pay attention to punctuations and size of the building. He presented some points for the student to focus on when writing their description of the rooms such as the size of the building, the things inside the building, the function of the building and the location of the object. In the other class, Gilang conducted several activities in the form of explanation and exercises to 
support his students to construct the expected text. He asked the students to read aloud a text of someone describing himself and family. The text had three paragraphs covering information of someone's identity, family members, and interests. $\mathrm{He}$ explained prepositions (in, on, and at), to be, reflexive pronouns, possessive pronouns, subjective pronouns, objective pronouns and some verbs. The grammatical points were based on the audio texts. He provided exercises for selfintroduction and family members. The exercises to learn about self-introduction covered arranging jumbled sentences based on an audio recording, self-introduction using cue cards, and spelling practice. The topic of family members was through reading out loud a passage, completing a family tree, and completing a passage by listening to an audio recording.

\section{Joint Construction}

Joint construction stage is the moment in which the teacher and students collaborate to construct the focus text. There was no activity of joint construction that can be identified both in Farhan and Gilang's classes. Farhan explained about how the students in their groups should do the final task of describing rooms in the school. He asked the students to do several things. First, they described the room as assigned on a piece of paper. It could be typed or handwritten. Next, they inserted photographs representing the objects in the rooms into their text. Finally, they recorded their description in videos.

\author{
S5: Hello, what's your name? \\ S6: My name is Ahmad (pseudonym). \\ S5: How many people in your family? \\ Banyak, pak. \\ T: Ga apa-apa. Sebutkan saja. \\ S6: My oldest sister, my older sister. \\ S5: What name your father? \\ S6: My father name is Dedy Hemawan (pseudonym). \\ S5: What is his occupation? \\ S6: My father occupation is err... businessman. \\ $\mathrm{T}$ : What is next question? Pertanyaan selanjutnya apa? \\ S5: What is your mother's name? \\ S6: My mother name is Rani (pseudonym). \\ S5: What is her occupation? \\ S6: Designer. \\ S5: What is your sister's name? \\ S6: My sister's name is Wina (pseudonym). \\ S5: Where does she study? \\ S6: In ... (saying a name of a school). \\ Excerpt 4 Gilang's Class Meeting 3
}

S6: There are eight people in my family, my father, my mother, my older brother, my...

Gilang, on the other hand, asked his students to copy a family tree and complete the missing name of family members showed on the screen to their note books. Then, he asked his students to work in pairs to interview each other about family members. He displayed the questions on the screen so that the students could read the questions to ask their partners. By looking at the screen the pairs asked and answered the questions of family members, e.g. father's name and profession. Sometimes the teacher reminded S5 to ask the next question. The students made some grammatical mistakes when the questions and answers were delivered, even though they looked at the screen. The teacher did not give any correction and let the interview session went on.

\section{Independent Construction}

After working in collaboration of organizing the focus text, students are usually ready to write their own texts. Both Farhan and Gilang's class showed that the students were occupied to write their descriptions in their desks. The teacher walked around the room and sometimes responded to students who went to him. The difference is that the number of students who completed the task. Farhan assigned his students to work in pairs, while Gilang asked his students to write the texts individually.

The last meeting in both classes was used for drafting the target text and explaining grammatical points. The students did their task to construct their texts after the teachers provided some explanation of the grammatical points they thought to be important for their students to pay attention when construction their texts. In addition, in Gilang's class, the students read aloud the text in the previous meeting in regards with correcting the students' pronunciation. He also taught his students to do clustering activity to group information to be included in their texts. The clustering activity was similar to creating a web map that was believed by the teacher to help the students to remember what information they should cover in their texts. 


\section{Students' Texts}

In addition to the data taken from the observation to identify the stages of genre-based pedagogy conducted by two EFL preservice teachers, the following is the finding taken from the students' texts. The focus text to be written by the students was descriptive report. One sample text was taken for analysis from each class.

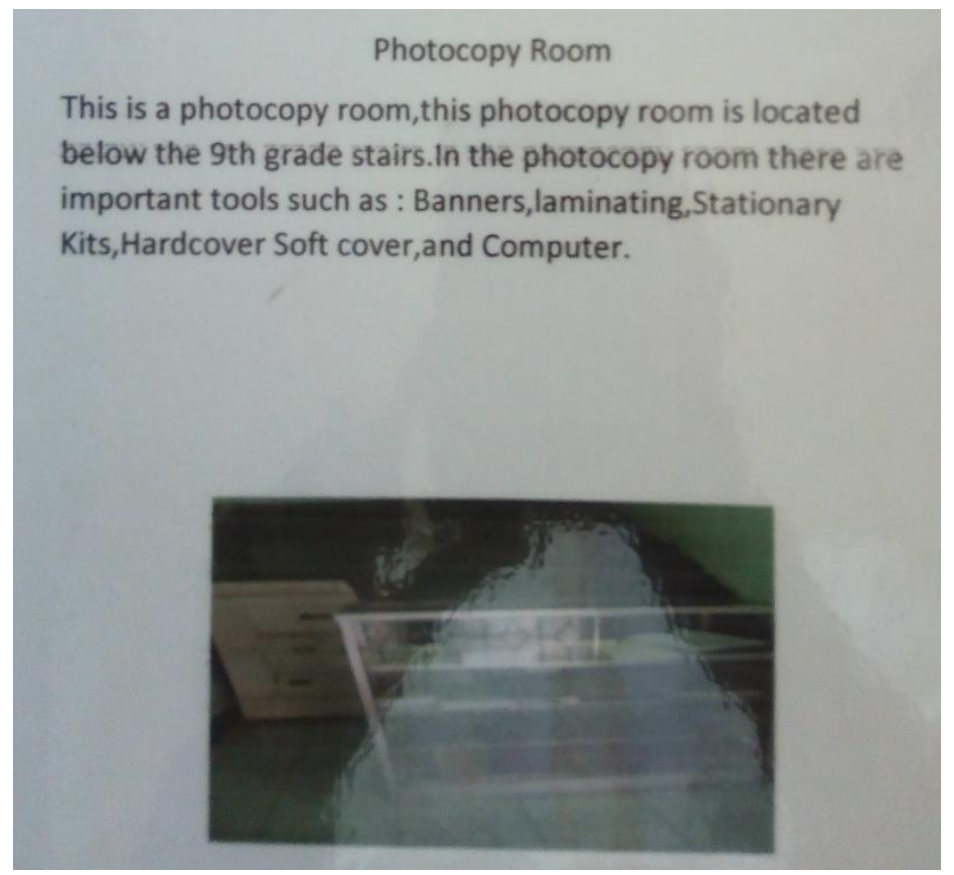

Figure 3 A Sample of Students' Texts in Farhan's Class

The result of the learning in Farhan's class is that the students were expected to construct a text of describing a room in their school. The above sample is the text constructed by a pair of students describing a place used as a copy center in the school. The text consists of a title and a paragraph. The title shows the room that was being described in the text, and the paragraph describes the location of the room and some objects found in the room. Regarding the structure of the descriptive report, the text has a general statement and some descriptions such as the location of the room and the items that could be found in the room. However, the text does not show appropriate forms of sentences. The identification and descriptions stages could be assessed appropriately as a good descriptive report text usually shows. For example, the first sentence consists of two sentences, one sentence as the identification that is to be elaborated or specified in the second sentence. The second sentence should be written separately as a new sentence.

Looking back at the clues that the teacher had given to the students, the text does not suit some of the criteria. They are size of the room, function of the room, location of the objects in the room and punctuation. Descriptions of the size of the room, function of the room, and location of the objects in the room are missing in the text. Some objects are mentioned by they are not described in terms of positions. In addition, the punctuation and capitalization are not appropriately used in the text. Nevertheless, the linguistic features that can be identified in the text are relatively appropriate, e.g. the plural forms of objects and 'be'. 


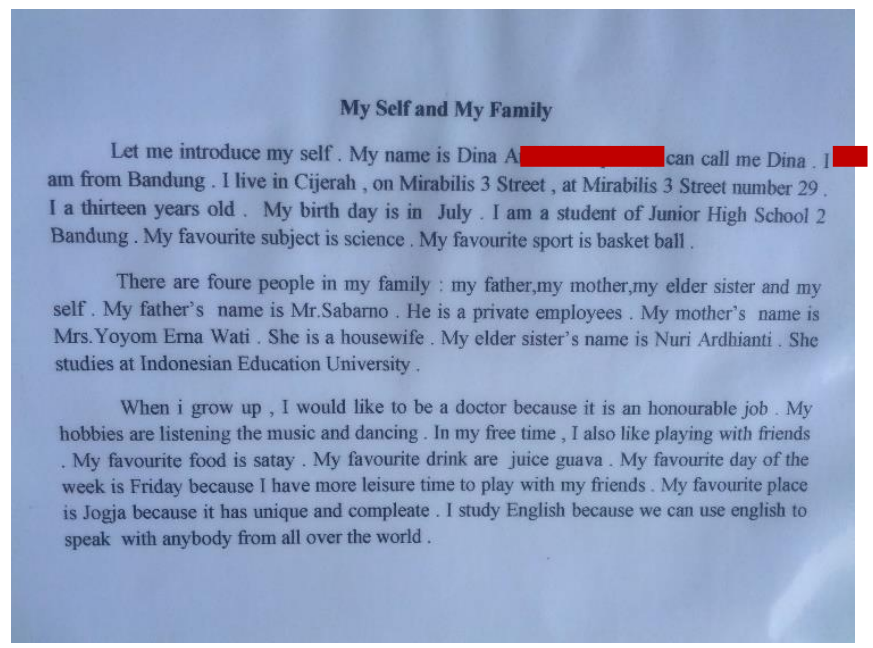

Figure 4 A Sample of Students' Texts in Gilang's Class

The text above is a sample text produced by a student in Gilang's class. The text is a result of learning in the last meeting. This is the revised version after the teacher gave some feedback to the text. In terms of structure, the text has a title and general statement. The descriptions include the writer's identity, family, dream job, and favorites. The text has more or less similar structure and development of a descriptive report as the text presented by the teacher in Meeting 4. It seems that the text helped the students to write their own text. The activity of clustering technique even assisted the students to be aware of what information to be included into the text they were developing. However, the teacher missed to identify inappropriate use of punctuations in his feedback.

\section{DISCUSSION}

Based on the data analysis, EFL preservice teachers in this study are be relatively knowledgeable of the stages of genre-based pedagogy in order to support their students to be able to construct the focus genre targeted in their units. Both teachers expected their students to be able to write descriptive reports. In the purpose to assist their students' writing ability, the preservice teachers supported their students by showing input in in the forms of videos, audios, printed materials, and slide shows containing texts, grammar points, and exercises. In the first stage, both preservice teachers focused the lesson on introducing the topics using videos in English voices. They attempted to provide examples of objects and introduction in the focus language. In the next stages, they supported their students to be able to construct the focus texts by providing explanations and exercises that focus on grammar and related vocabularies, even though none of them seemed to pay attention to how the sample texts were structured. They tended to focus on the texts, in form of audio visual and written, to be exposed to their students with relatively little discussion, and to grammatical elements that they expected their students could form when constructing their texts. The text expansion was shown by Gilang who provided gradual expansion in terms of information covered in the texts. In the first meeting, the text only covered name, origin, and address. In the second meeting the coverage of the text was expanded by adding interests and favorites and in the third meeting information of family members and dream job was added into the text. He also provided a list of occupations to help the students identify the English names of certain occupations. The activity in which the teachers and students collaborate with each other to construct the focus text did not take place in both classes in the joint construction stage. In practice, the activity that could be identified were that the teachers let the students themselves do the final task in groups (Farhan's class) and observed the students to practice giving questions and answers (Gilang's class). The teachers did not provide their students of the sample text they were supposed to construct, but they provided clues of what to be there in constructing the text or the conversation.

The use of genre-based pedagogy in teaching writing has proven to support students to be able to write the focus genre. Studies reported that this pedagogy has been successful to support preservice and in-service teachers to help their students to write (Hyland, 2007). Specifically, it has helped students in different contexts of teaching such as ESL/EFL contexts, CLIL contexts, and the teaching of non-English subjects (Cahyono, 2017); Lo \& Jeong, 2018; and de Oliveira \& Lan, 2014). Through its special ways of scaffolding students, genre-based pedagogy, students learn how language functions in texts and how texts are developed through their purpose and stages.

However, the result of the support provided by the EFL preservice teachers in this study identified through the texts written by their students seemed to be lack of development, especially the texts written by Farhan's students. As in the display of the sample text, the structure of the text could not be identified. Instead of structuring the text of descriptive report with identification and descriptions, the information in the text is mostly mentioning the objects found in a room called photocopy 
room. A better text was displayed by Gilang's students of which their texts showed appropriate structure of descriptive report.

The results of the student learning through the show of the students' written texts can be a reflection of what had been occurred in the classroom during the implementation of genre-based pedagogy. Observing the first class, the teacher expected the students to work together in groups to describe objects (things in the classrooms and parts of the school) as the results of their learning. However, the activities in did not reflect the essence of what the genre-based pedagogy stages have. The activities seemed to be attempting to equip the students with knowledge and practice with little or no practice to develop the expected text. On the other hand, the preservice teacher in the second class had quite good awareness of the stages that he thought he had to follow consistently and of the students' need to have exposure to the text they were going to produce, orally and in written. He also helped his students to learn the grammar that was needed to support their writing so that their writing could be meaningful. This preservice teacher had more knowledge of how to provide exposure to his students, not just focusing on grammar but also on the target text the students were expected to produce. However, both preservice teachers showed their lack of understanding on stage of modelling and joint construction in which the activity should be more on writing together as a class. Those are the stages students are made aware of the structure and language features of the focus text and where students have an opportunity to experience to write the text together with their friends and teacher (Hyland, 2003; Derewianka, 2003). Here, students as a group work and learn together to create the target text with their teacher. The special technique, what Gilang called as clustering technique, would be more beneficial if it had been an activity in modelling stage. This activity could be used as deconstructing the sample text to cluster the vocabularies used in the text.

Referring to the type of teachers in this study, i.e. EFL preservice teachers, the weaknesses of the implementation of genre-based pedagogy in their classes are tolerable in the ways that the teachers were in the process of learning through joining the professional program of field experience or teaching practicum. The preservice teachers were being trained to experience real-world setting to develop their skills and knowledge professionally (Mtika, 2011; Gebhard, 2009). Therefore, modification or adaptation might occur towards the stages and activities of genre-based pedagogy. As shown by the studies conducted by de Oleivera and Avalos (2018) and Correa and Echeverri (2017), the preservice teachers modified the stages into building the field, assessing understanding and pre-writing, deconstruction of text and co-construction of text. In addition, Yayli (2011) suggests that preservice teachers should experience the instruction of using genre-based pedagogy of how texts are constructed so that they can be trained of genre awareness and language teaching.

This study adds the literature of recontextualisation of genre-based pedagogy in Indonesian context. It supports the findings in Kartika-Ningsih and Gunawan's study (2019) that is EFL teachers in Indonesia have recontextualised the model of genre-based pedagogy that is more or less influenced by their knowledge of other approaches of teaching English. The Indonesia model version of genre-based pedagogy focuses students to grammar mastery with limited practice of texts construction.

\section{CONCLUSION}

Genre-based pedagogy is one of the teaching and learning strategies to assist students to develop their literacy in language, especially English language. It has special stages that scaffold students to reach their ability to write texts for different purposes. Teachers may creatively design the activities in order to make their students aware of the purpose of the target text and the structure of the text. They also lead to pay attention to the grammatical element of how to make the text meaningful. They can be considered as more or less successful to help their students to develop their text, written and spoken, despite some inappropriate activities. Model texts play significant role in showing how the target text should be developed by the students. Special techniques such as clustering technique and video presentation helped the students in such a way that they could enjoy the learning and focus on the target text.

However, the preservice teachers needed to be more selective in deciding which texts to be modeled because the students would tend to follow the model text for their text construction. Texts that are selected have to be well developed in terms of purpose, structure and language (Christie, 2004). They also had to be more careful in designing activities in the stages of modelling and joint construction. Those stages are the activities in which students identify the focus text structure and language features, and practice writing in collaboration between teacher and students.

There are several limitations of this study. First, it focused only on the implementation of genre-based pedagogy by EFL preservice teachers. It did not include the university supervisor and cooperating teacher who supervised the preservice teachers. Second, it did not consist of interviewing the participants of the study. The inclusion of interview may bring new insights of how the preservice teachers could voice their ideas and experiences in the implementation of genre-based pedagogy in their classes.

Based on the study some recommendations are proposed for the further studies in the context of teaching practicum. First, the study may focus on the role of supervisor and cooperating teacher in the application of genre-based pedagogy by preservice teachers. Second, the collaboration between supervisor/cooperating teacher and preservice teachers in applying genre-based pedagogy is also promising to be explored. Third, the inclusion of more instrument may enrich the data collection to have more exploration of the issue of genrebased pedagogy application in EFL settings. 


\section{REFERENCES}

Aunurrahman, Hamied, F. A., Emilia, E. (2017). Exploring the tertiary EFL students' academic writing competencies. Indonesian Journal of Applied Linguistics, $7(1)$, 72-79. https://doi.org/10.17509/ijal.v7i1.6860

Burgos, E. G. (2017). Use of the genre-based approach to teach expository essays to English pedagogy students. How. 24(2), 141159. https://doi.org/10.19183/how.24.2.330

Cahyono, S. P. (2018). Teaching L2 writing through the use of Systemic Functional Linguistics (SFL). Indonesian Journal of English Language Teaching, 13(1), 53-72.

Christie, F. (2004). Systemic functional linguistics and a theory of language in education. Ilha do desterro, $46,13-40$

Christie, F., \& Derewianka, B. (2008). School Discourse: Learning to write across the years of schooling. London, UK: Continuum International Publishing Group.

Correa, D., \& Echeverri, S. (2017). Using a systemic functional genre-based approach to promote a situated view of academic writing among EFL preservice teachers. HOW, 24(1), 44-62. http://dx.doi.org/10.19183/ how.24.1.303

de Oliveira, L. C., \& Avalos, M. A. (2018). Critical SFL praxis among teacher candidates: Using systemic functional linguistics in K-12 teacher education. In Harman, R. (ed.), Bilingual Learners and Social Equity, Educational Linguistics 33 (pp. 109-123). Springer International Publishing AG. DOI 10.1007/978-3-319-60953-9_6

de Oliveira, L.C., \& Lan, S.-W. (2014). Writing science in an upper elementary school: A genre-based approach to teaching english language learners. Journal of Second Language Writing, 25, 23-39. http://dx.doi.org/10.1016/j.jslw.2014.05.001

Derewianka, B. (2003). Trends and issues in genrebased approaches. RELC Journal, 34(2), pp. 133154.

Derewianka, B., \& Jones, P. (2016). Teaching language in context (2nd Edition). Sydney, Australia: Oxford University Press. https://doi.org/10.1177/003368820303400202

Eggins, S. (1994). An introduction to systemic functional linguistics. London, Great Britain: Biddles Ltd.

Emilia, E. (2011a). Pendekatan genre-based dalam pengajaran bahasa Inggris: Petunjuk untuk guru. Bandung, Indonesia: Rizqi Press.

Emilia, E., \& Hamied, F. A. (2015). Systemic functional linguistic genre pedagogy (sfl gp) in a tertiary EFL writing context in Indonesia. TEFLIN Journal 26(2), 155-182. http://dx.doi.org/10.15639/teflinjournal.v26i2/155$\underline{182}$

Feez, S. (2002). Heritage and innovation in second language education. In A. M. Johns (Ed.), Genre in the classroom: Multiple perspectives (pp. 43-69).
Mahwah, NJ, USA: Lawrence Erlbaum Associates, Inc.

Gardner, P., \& Bartkus, K. R. (2014). What's in a name? A reference guide to work-education experiences. Asia-Pacific Journal of Cooperative Education, 15(1), 37-54. https://doi.org/10.1007/s12564-0139295-4

Gebhard, M., \& Harman, R. (2011). Reconsidering genre theory in K-12 schools: A response to school reforms in the United States. Journal of Second Language Writing, 20, 45-55.

Gebhard, M., Chen, I. A., Graham, H., \& Gunawan, W. (2013). Teaching to mean, writing to mean: SFL, L2 literacy and teacher education. Journal of Second Language Writing, 22, 107-124. https://doi.org/10.1016/j.jslw.2010.12.007

Gebhard, J. G. (2009). The practicum. In A. Burns \& J. C. Richards (Eds.). The Cambridge guide to second language teacher education. Cambridge University Press. https://doi.org/10.1016/j.jslw.2013.03.005

Goh, P. S., \& Matthews, B. (2011). Listening to the concerns of student teachers in Malaysia during teaching practice. Australian Journal of Teacher Education, 36(3), 92-103. https://doi.org/10.14221/ajte.2011v36n3.2

Hariyanto, S. (2001). ReciProcal Teaching and GenreBased Approach Combination: Proposed Strategy in Business English Classes. TEFLIN Journal, 12(2), 253-266.

Hasan, M. K., \& Akhand, M. M. (2010). Approaches to writing in EFL/ESL contexts: Balancing product and process in writing class at tertiary level. Journal of NELTA, 15(1), 77-88. https://doi.org/10.3126/nelta.v15i1-2.4612

Hoverak, M. O. (2016). An experimental study on the effect of systemic functional linguistics applied through a genre-pedagogy approach to teaching writing. Yearbook of the Poznań Linguistic Meeting. 2, 67-89. doi: 10.1515/yplm-2016-0004

Hyland, K. (2003). Genre-based pedagogies: A social response to process. Journal of Second Language Writing, 12(1), 17-29. https://doi.org/10.1016/S1060-3743(02)00124-8

Hyland, K. (2007). Genre pedagogy: Language, literacy and. Journal of Second Language Writing, 16, 148164. https://doi.org/10.1016/j.jslw.2007.07.005

Kartika-Ningsih, H., \& Gunawan, W. (2019). Recontextualisation of genre-based pedagogy: The case of Indonesian EFL classrooms. Indonesian Journal of Applied Linguistics, 9(2), 335-347. https://doi.org/10.17509/ijal.v9i2.20231

Kemdikbud. (2013). Kerangka dasar dan struktur kurikulum sekolah menengah pertama/madrasah tsanawiyah. Jakarta: Kementerian Pendidikan dan Kebudayaan.

Knapp, P., \& Watkins, M. (2005). Genre, Text, Grammar. Melbourne, Australia: University of New South wales Press Ltd.

Lo, Y. Y., \& Jeong, H. (2018). Impact of genre-based pedagogy on students' academic literacy 
development in content and language integrated learning (CLIL). Linguistics and Education, 47, 3646. https://doi.org/10.1016/j.linged.2018.08.001

Min, Z. (2014). Suitability of genre approach in China: How effective is it in terms of SLA for Chinese University Students to Improve Their Listening Skills?. International Journal of Humanities and Social Science Invention. 3(6), 57-63.

Mtika, P. (2011). Trainee teachers' experiences of teaching practicum: Issues, challenges, and new possibilities. Africa Education Review, 8(3), 551567. https://doi.org/10.1080/18146627.2011.618715

Noriega, H. S. R. (2016). Mobile learning to improve writing in ESL teaching. TEFLIN Journal, 27(2), 182-202. http://dx.doi.org/10.15639/teflinjournal.v27i1/182 202

Pujianto, D., Emilia, E., \& Ihrom, S.M. (2014). A processgenre approach to teaching writing report text to senior high school students. Indonesian Journal of Applied Linguistics, 4(1), 99-110. doi: 10.17509/ijal.v4i1.603

Ragawanti, D. T. (2015). Cultivating pre-service teachers' classroom management skills through teaching practicum: A reflective practice. TEFLIN Journal, 25(1), 117-128. https://doi.org/10.15639/teflinjournal.v26i1/117-128

Rodríguez, A. G., \& McKay, S. (2010). Professional development for experienced teachers working with adult English language learners. www.cal.org/caelanetwork
Rothery, J. (1994). Exploring literacy in school English (Write it right resources for literacy and learning). Sydney: Metropolitan East Disadvantaged Schools Program.

Simons, L., Fehr, L., Blank, N., Connell, H., Georganas, D., Fernandez, D., \& Peterson, V. (2012). Lessons learned from experiential learning: What do students learn from a practicum/internship?. International Journal of Teaching and Learning in Higher Education, 24(3), 325-334.

Tuli, F., \& File, G. (2009). Practicum experience in teacher education. Ethiop. J. Educ. \& Sc.5(1), 107116. https://doi.org/10.4314/ejesc.v5i1.56316

Worden, D. (2018). Balancing stability and flexibility in genre-based writing instruction: A case study of a novice L2 writing teacher. Journal of Second Language https://doi.org/10.1016/j.jslw.2018.09.003

Worden, D. (2019). Developing L2 writing teachers' pedagogical content knowledge of genre through the unfamiliar genre project. Journal of Second Language Writing,

46. https://doi.org/10.1016/j.jslw.2019.100667

Yasuda, S. (2011). Genre-based tasks in foreign language writing: Developing writers' genre awareness, linguistic knowledge, and writing competence. Journal of Second Language Writing, 20 , 111-133-112. https://doi.org/10.1016/j.jslw.2011.03.001

Yayli, D. (2011). From Genre Awareness to Cross-Genre Awareness. Journal of English for Academic Purposes, 10, 121-129. https://doi.org/10.1016/j.jeap.2011.02.001 